\title{
The relation between church and
}

\section{world/culture in view of the Pauline \\ "as if not" (}

\author{
G M M Pelser \\ Emeritus Professor: Department of New Testament Studies \\ University of Pretoria
}

\begin{abstract}
In this study, the question is posed whether Paul was of the opinion that, apart from proclaiming the gospel, the church should be involved in cultural matters and even take responsibility for furthering cultural causes. The study focuses on to Paul's advice to his readers in 1 Corinthians 7:17-24, and especially 7:29-31. Concerning the latter passage, the possibility of Stoic influence on Paul is weighed and, although such influence is not ruled out altogether, it is argued that Paul's advice should rather be seen against the background of his expectation of the imminent end of the world, as well as his conviction that the believer's union with Christ makes any other relationship or involvement a matter of no consequence. The final conclusion of the study is that although Paul did not advocate asceticism or forbid Christians to take part in worldly matters and institutions, he did not expect them to play an active role in these things or to promote culture either. On this basis, it is concluded that Paul may not be used in support of any argument in favour of a cultural involvement or responsibility on the part of the church.
\end{abstract}

\section{INTRODUCTION}

The question of the relation between church and culture is, in a certain sense, a modern question. It is a question which has increasingly come to the fore as, among other things, greater insight was gained into the New Testament's understanding of the church, even though this understanding is characterised by considerable diversity (see Käsemann 1960; Schnackenburg 1974; Roloff 1993; Pelser 1995). What gained particular prominence was the insight that the church and the world are two qualitatively different entities, mutually exclusive and distinc from each other. This fact makes it essential to reconsider the relationship between the two, especially as the two entities 
have either frequently strayed onto each other's territory or become entwined in some way with each other, or tried to gain certain benefits from each other. Though it has often happened that the world or a culture wanted to usurp the church conform, the church is undoubtedly the greatest culprit since it has tried all too often to stamp a "Christian" character on virtually every institution or activity in society. This emanates, of course, from a particular theocratic approach existing in the church (more strongly in some denominations than in others) that wants to claim the whole of society for God and establish the kingdom of God on earth. Although this tendency has diminished to some extent, one still vividly remembers how lavishly the label "Christian" was applied to secular organisations and enterprises which had nothing to do with the church or the Christian faith. What is even more disturbing, is how often the church was misused, and even hijacked, to sanction or lend credibility to sometimes dubious political programmes. This occurred across the entire political spectrum in South Africa, and has not yet - and probably never will come to an end.

The short and generalised outline above suffices to underline the need to consider anew and continuously the difficult question of the relation between church and culture. It is no easy task to answer this question on the basis of the New Testament. The main reason is that the New Testament does not deal specifically with this question, and that whatever one wishes to say about this on the basis of the New Testament has to be said only by way of deduction or based on conjecture, and this applies to Paul as well. It is in addition striking that not even in the secondary literature has much or profound attention been given to the matter, so that one walks a fairly lonely road in search of an answer. The study below takes the form of a few propositions, each of which is motivated by Pauline pronouncements and are briefly deliberated further. Except for the last two propositions, however, they are not all discussed extensively since, as the title of the study indicates, the emphasis falls on the $\omega s \mu \eta^{\prime}$ idea in 1 Corinthians 7:29-31. The first few propositions should therefore in a certain sense be seen as precursors to the later ones.

\section{THE NON-BELIEVING WORLD}

Paul always judges the non-believing world (humankind) negatively, and this judgement should probably also apply to specific world institutions as human inventions.

It is said of this world that it is under the control of the elements of this world, the spiritual powers and the god of this world (1 Cor 2:6, 8; 2 Cor 4:4; Gl 4:3), that it is godless (Gl 1:4) and hostile to God (1 Cor 2:6, 8), that it has 
exchanged God (his $\delta \sigma^{\prime} \xi \alpha$ ) for idols ( $R m$ 1:23), that what applies and is thought in it, is contrary to what God thinks and wills (1 Cor 1:20-28; 2:12; $3: 19$ ), that the wisdom of this world is foolishness to God (1 Cor 3:19), that it is sinful and therefore punishable before God and is alienated from his glory $(\mathrm{Rm} 3: 19,23)$, that it is rapidly speeding to an end (1 Cor 7:31) and that it will be condemned (1 Cor 11:32). However, it is also said of this world that it has been reconciled with God (2 Cor 5:19), referring to the possibility which was opened up in Christ for all people to be set in the right relationship with God. But this possibility does not deny that the Christian is urged not to conform to this world, that is that the Christian is urged not to adapt his/her new existence to the world (Käsemann 1974:315).

In this regard, Romans 13:1-7 seems to be a striking exception. As is known, this pericope presents a particularly complex problem. In the first place, not everyone is convinced that it was indeed penned by Paul's hand. For example, Schmithals (1994:242, 283-285), not wholly without justification, recently repeated his earlier standpoint (Schmithals 1975) that an editor had inserted the pericope to restrain Christians from rebelling, to their detriment, against the Roman government, and simultaneously to point out to the authorities that the Christians were law-abiding citizens who paid their taxes faithfully (see also Riekkinen 1980). But even if we did not want to take such a drastic view of this as Schmithals does, the pericope would still present a myriad exegetic problems (see inter alia Pelser 1986:516-524). Certain propositions in the pericope, in particular the proposition that the government is an institution of God, has in the history of its interpretation often been experienced as hard to accept. Similarly, the call to submit to the government has caused unease at the thought that this might presuppose an unconditional subservience and be intended to apply at all times (see again Schmithals 1994:285). Even a superficial glance at the literature about this pericope shows how attempts were made to overcome the exegetical problems, for

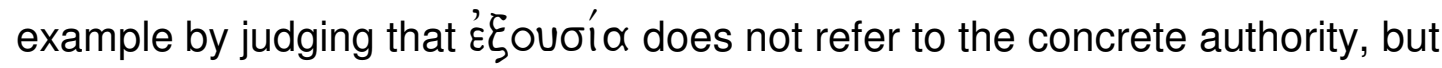
to angelic powers behind the authority, or that the call for subjection was situation-specific and therefore would not apply - at least not to the same degree - to the times thereafter (see again Pelser 1986:521-523). We shall return to this matter later.

\section{FREE TOWARD THE WORLD}

Whoever has become a believer (Christian) stands free toward the world and is free from the world.

This fact is expressed in a most radical form in Paul's proposition that the world is crucified unto the believer, and the believer unto the world (Gl 
6:14). The "l" used in this text has a double reference. On the one hand, it refers to the "old" person that formed part of the nature of creation that also qualifies the world, but it is a disqualifizierte Kreaturlichkeit (Oepke 1964:161). This is the "crucified" person (Rm 6:6) who, through faith, has made the cross of Christ so much his/her own that he/she has allowed himself/herself to be crucified (Bultmann 1968:303). On the other hand, this "I" refers to the "new" person (2 Cor 5:17; Gl 6:15) who, through the cross, has become "free" and no longer has any ties to the world. That the world is "crucified unto me" can hardly mean anything else than that my life is no longer determined by my nature of creation, my desire for the world, and I can no longer look to the world or to history for my salvation. But I am also crucified unto the world, that is the world no longer has any claims on me and no longer determines my existence.

There can be no doubt about the radical nature of the break with the world that is indicated by this state of reciprocal crucifixion. Betz expresses it

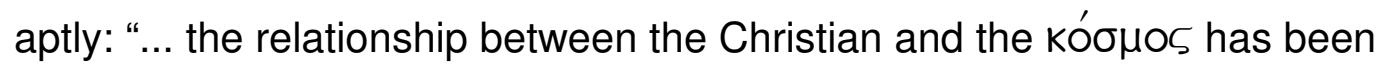
"crucified"' (Betz 1979:319). When applied to the church, it implies that the church and the world have nothing in common, and especially that the church may not make common cause with the world.

\section{PARADOXICALLY SEPARATED}

Because of their new bond, Christians live separated from the world, but in a paradoxical sense because a Christian existence is realised nowhere else but in the world, with everything that is current in it.

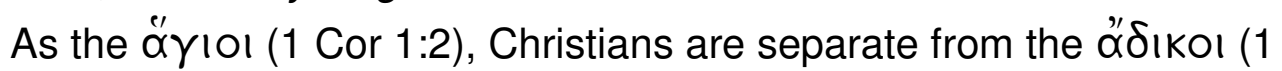
Cor 6:1, 9); as the mıбтоi they are to be distinguished from the $\alpha$ míotol (1 Cor 6:6), as they who are "in here" (the insiders = of है $\sigma \omega$ ) they stand opposite those who are "out there" (the outsiders = of ह ह $\xi \omega-1$ Cor 5:12-13; । Th 4:12). We have here a typically Pauline division of people into two groups - those who belong to the church and those who do not. We have every reason to believe that the Old Testament view of Israel as a chosen people set apart from the others, played a role here (see Neyrey 1990:41). Yet the locus of being church can be nowhere else than in the world. To be church is to be church in the world. It is indeed not possible for Christians to isolate themselves physically from the world (1 Cor 5:10). Consequently, the relation of the church to the world is a relation of paradoxical separation. On the one hand, the church is called out of the world; on the other, the church can only fulfil its being the church by proclaiming its message in the world. What enables the faithful to keep the world at a distance while paradoxically living in it, is the freedom with which they confront the world in their new bond with 
Christ. This is why they can buy meat (dedicated to an idol) from a butchery or go to dine with an unbeliever without any qualms (1 Cor 10:25, 27); they are detached from such matters (see Conzelmann 1969:208-209). Their faith does not depend on what they buy in the market or with whom they share a meal.

\section{BEING CHURCH AMID A DIVERSE SOCIETY}

As all worldly distinctions have become irrelevant and meaningless in the church, the church cannot be expected, nor is it the business of the church, to campaign for maintaining in society that which no longer has any validity in the church.

If Paul's pronouncement in Galatians 3:28 (cf 1 Cor 12:13) is understood correctly and taken seriously, it implies that attempts by the church to maintain or extend worldly distinctions and groupings outside its territory would be in conflict with the nature and calling of the church. The church may therefore not at one minute schizophrenically form a distinctionless community and the next minute advocate the opposite. If it did, the church would wage an irreconcilable conflict with itself and experience an insoluble identity crisis. On the other hand, however, there is no indication that Paul held the view that the church had to attempt to convey this distinctionlessness to the world and tries to make it a global programme. Then the church would enter the territory of the world and attempt to turn the world into a sacred space. The world cannot be made into a sacred space, because the world simply cannot be one. The church would then run the risk of reactivating the distinctions, but under a Christian banner (rightly so, Conzelmann 1968:289-290). Obviously, in this regard too the church lives in a paradoxical situation, because it exists as an entity without distinctions and status within a society in which these distinctions are present. But this is precisely the miracle of the fruit of the gospel: that it is in fact possible to be church in such a situation and that the church is realised across differences and boundaries. The true character of the church is not expressed in attempts to establish a global utopia of sameness and equality, but precisely in its ability to be church amid and despite all these differences. The following remarks made by Käsemann regarding the Pauline congregations can to a large extent also be applied to being church in a diverse society: Paul did not advocate uniformity in his congregations, but solidarity. People who are all the same have nothing to say to one another and cannot assist one another. The necessity and the blessing of Christian freedom are actually not to give to each the same, but to give and let each have his or her own. Sameness (Gleichheit) "ist der Todeszustand der Solidarität” (Käsemann 1972:206). 


\section{BEING A CHRISTIAN INDEPENDENTLY OF STATUS OR SITUATION}

The irrelevance of worldly norms, distinctions, bonds, profession, status and circumstances to the ecclesiastical sphere is also manifested in being a Christian wholly independently of worldly trappings.

It is for this reason that Paul advises the faithful to remain in the same circumstances as they were when they came to faith (1 Cor 7:17-24). The reason is obvious, namely that the external position or circumstances of the believer lose their significance since before God and in the congregation, other criteria and values apply (Klauck 1984:54). Moreover, it seems that no one may rely on his/her calling by God as an excuse or motivation to change his/her living conditions, social status or family context (Schrage 1995:134). Although Paul has often been accused of holding a conservative ethical view, especially with regard to the situation of slaves, it does not seem fair to accuse him of this on the basis of this text. He does not object to change because of a conservative attitude, as if he assigned to the status quo a value of its own or would sanction it as an intangible divine arrangement. He is less concerned with the $\mu \varepsilon^{\prime} \nu \varepsilon I \nu$ in the given circumstances than with the

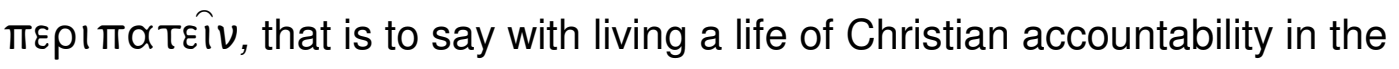
environment in which the believer received God's calling (rightly so Schrage 1995:134-135). What it all comes down to is that every place where one may find oneself in one's daily life is a place in which the Christian life can be lived. We are free and equal, not because we are equal as people but because everyone is free wherever he/she may be (rightly so Conzelmann 1968:303). It therefore follows that it is illusory to think that there are places that guarantee salvation and other places that can threaten it. The call for everyone to remain in his/her $\mathrm{k} \lambda \hat{\eta} \sigma \mathrm{I} \zeta(1$ Cor 7:20) is a dialectical call: it is not based on the assumption that one's profession or social status has particular merit or is an organising principle of creation and therefore holy, but precisely on its not being that. The event of salvation has neutralised it to the purely human level, which can neither claim nor prevent faith (see Conzelmann $1968: 304 ; 1969: 151)$. One should remain in one's situation, precisely to avoid succumbing to the illusion that one can do anything about one's salvation by changing one's human status. What is decisive for being a Christian is not where one lives as a Christian, but how one is a Christian there. One must therefore be a Christian inside the structures and sectors of this world, not in some pious ghetto or ivory tower shielded from daily realities (Schrage 1995:135). The church consists of people already liberated from this world and therefore no longer needing to distance themselves from the world in order to share in salvation. Conzelmann rightly points out that if the church 
were to become completely detached from the civil order, the church would itself have to institute a "Christian" order, which would then per se have to be regarded as sacred - an idea the church has in fact rejected (Conzelmann 1968:281). The irrelevance of and disregard for worldly distinctions therefore does not presuppose that the church should launch a sociological programme in the world, but is an eschatological event which becomes a reality only within the eschatological congregation (Bultmann 1968:310). Of course, this argument cannot be pursued ad absurdum. It can therefore not be used to condone sinful practices. For instance, it is not possible to argue that a prostitute or swindler may simply carry on with her or his practices. Life circumstances, status or position do not add anything to or detract anything from being a Christian. This fact should be considered all the more seriously against the background that the world in its present form will, as Paul puts it, soon be gone (1 Cor 7:31). The world, with what is peculiar to it and in which it comes into being, therefore has no permanence on which one can build and no eternal value that can be pursued. More about this later.

\section{THE "AS IF NOT” OF THE RELATION BETWEEN CHURCH AND WORLD/CULTURE}

There is really only one guideline for the way in which Christians are supposed to be involved with the world, and that is that they should have a part in it as if they had no part in it (⿳亠丷厂s $\mu$ ń).

The view has been held for some time that the advice Paul gives his readers in 1 Corinthians 7:29-31 has parallels in the Cynic-Stoic ideal of 'ं $\alpha \rho \propto \xi^{\prime} \propto \alpha$ (= indifference, emotionlessness, apathy), the ideal of inner detachment from all externalities and earthly ties and of an impassive equanimity toward all adversity and conditions of life, whether good or evil. Weiss (1970:198), for instance, contends that the "innere Losgelöstheit, die hier gefordert wird" finds its parallel in Epictetus (Diss III 24:59v), but he does not think Epictetus' view can quite be reconciled with Paul's positive attitude to certain matters, such as the relationship between man and woman.

If the question of Cynic-Stoic influencing is considered in real earnest, it soon becomes clear that it is not very easy to argue for or against it because, though there is apparently a degree of correspondence there are important differences too. One should guard in particular against simply accepting verbal similarities as parallels without considering the context of or the reasons for standpoints in the assumed parallel.

It is true that the Stoics were convinced that withdrawing into one's inner self and distancing oneself from externalities made one independent of the worldly matters one cannot control, but it cannot control one's life either. 
These include things such as one's body, possessions, children, family, friends, status and reputation. The Stoic view is that one has no control over

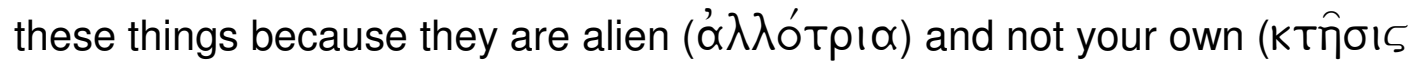

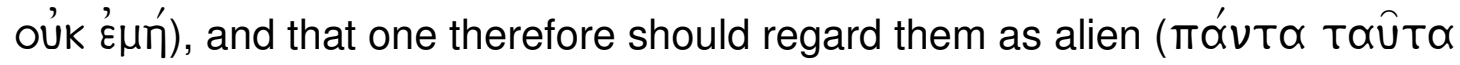

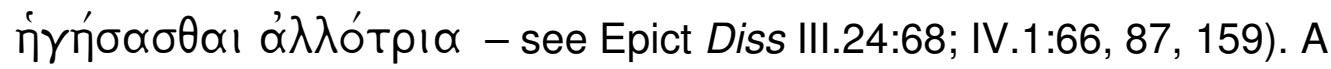
person who feels the grief of parting from or joy about something or someone, is reminded that he/she is making the error of regarding $\alpha \lambda \lambda$ ót $\rho ı \alpha$ as $^{\prime} \delta 1 \alpha$ (Epict Diss III.24:4). We are given something or someone only temporarily, not forever (Diss III.24:84-86). For this reason, Epictetus could recommend the Cynical attitude and lifestyle with regard to these things. Even without possessions, clothing, house or other dwelling, wife or child, the Cynic could still be happy (Diss III.22:45-49).

Earlier, Schrage (1964) attempted to argue that the text in question has no parallel in the Cynic-Stoic philosophy, namely in Epictetus, as in Schrage's opinion there are too many radical differences between Epictetus and Paul. He mentions differences such as the following: though is it true that both Epictetus and Paul want man to keep his heart free from worldly matters, Paul sets certain limits regarding man's non-involvement in matters of this world. For the Stoic, for example, sympathy is something negative; for Paul it is a particularly positive emotion. Paul regards as an illusion Epictetus' optimisticrationalistic idea of gaining control over oneself, and thereby over the world, through an inner withdrawal from the world. The notion that you can live unperturbed if you distinguish between what is "yours" and what is "alien" must, in view of Paul's thinking, be regarded as naïve, as it does not take external pressure into account $(\theta \lambda \hat{i} \psi \mid \zeta)$. Epictetus does not admit the existence of something like external pressure, because it is not things and

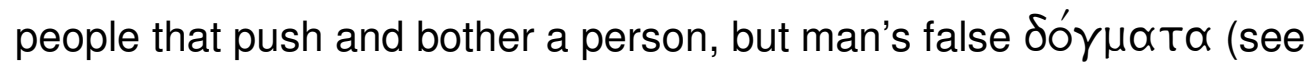
Schrage 1964:134-135). Apart from drawing these distinctions, Schrage regards as crucial the strong eschatological motivation for Paul's argument a motivation that does not feature among the Stoics. This made Schrage look to the apocalyptic literature, where he then believed he had found the corresponding parallel, namely in 4 Esra 16:42-45 (but see also Schade 1984: 101 for counter-arguments). The following are some examples from the above text: qui aedificat, quasi non habitaturus (he who builds a house, must be like one who will not live in it); qui nubunt, sic quasi filios non facturi (they who marry, must be like people who will be childless). According to Schrage (1964: 139-149), we are not dealing here with the dependence of one text on the other, or vice versa, but rather with the probability that both texts were derived from a common apocalyptic source. 
It is doubtful whether Schrage really succeeded in finding a suitable parallel in this way. Besides the eschatological atmosphere and the use of quasi, equivalent to $\dot{\omega} s$, which the Esra text has in common with the Pauline text, this text also does not appear to be a truly comparable parallel. Of the acts mentioned here, it is invariably said that their result will differ diametrically from the intended result, or it is said they will not have the presumed result. At the root of the matter, what we are dealing with here is that a situation is foreseen in which everything that could possibly be undertaken in the expected apocalyptic circumstances should be regarded as futile, since nothing undertaken would succeed. This is clearly not what the Pauline text wishes to convey, no matter how we should understand the latter. In other words, Paul's text definitely does not concern the opposite effect or the futility of the faithful's participation in worldly institutions or customs.

Fairly recently, Schrage (1995:172) had to revisit this text in his commentary on 1 Corinthians, and then he expressed the opinion that the words of Diogenes Laertes (6:29) could be regarded as the nearest Stoic parallel, although he points out that there are more points of difference than of correspondence between the two texts (the following will serve as examples:

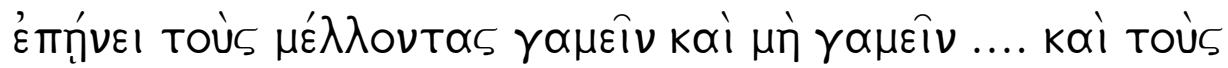

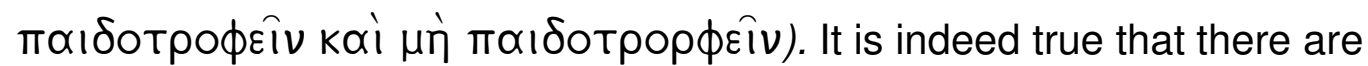

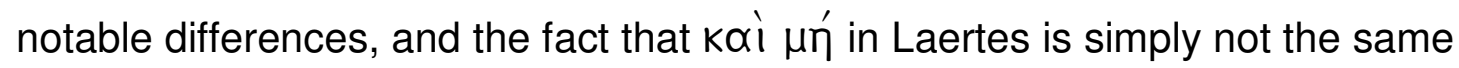
as $\omega^{\prime} \mu \eta \dot{n}$ in Paul, can be regarded as the most important. According to the quoted text, Laertes holds the view that people who for instance intend to get married, go sailing, meet important people, and so forth, and then in freedom decide against carrying out their intention, should be praised. In Paul's text, it is a completely different matter. His point is that circumstances which arose through the Christ event, have cast a different light on participation in worldly institutions and matters, giving them a different value and significance.

Although it seems that neither of the above-mentioned parallels really fits, there are nevertheless two cases in Epictetus which come fairly close to what we have in Paul (see also Deming 1995:191). The first case concerns a man who does not rate his person higher than its divinely granted value. It is said of such a person that if he displays this same attitude to his possessions, his wife and his children, and he acts as if it does not matter whether he has

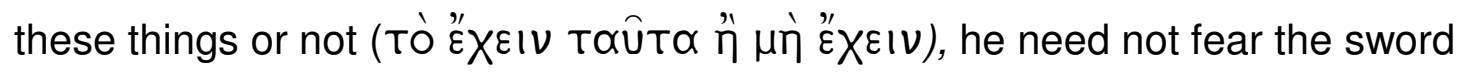
of tyrants or bodyguards (Diss IV.7:5). In the second case, Epictetus says of Socrates that although he had a wife and children, he did not regard them as

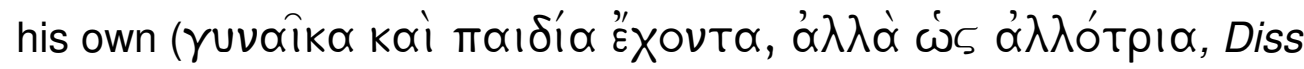
IV.1:159) and that when he had to defend himself at his trial he did not speak 


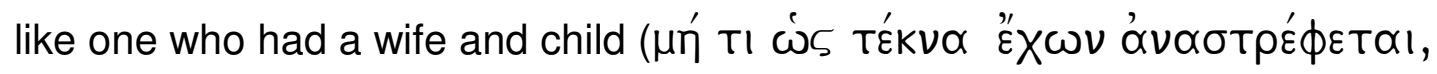

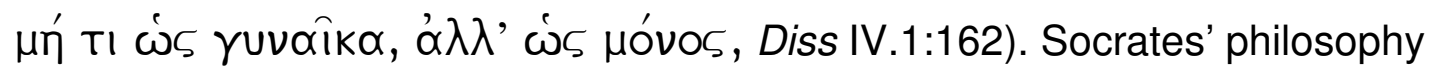
of life as formulated here corresponds fully to the Stoic ideal of not being dependent on people or possessions. And it is an ideal that remains valid at all times and in all circumstances. Whether this corresponds fully with Paul's words in 1 Corinthians 7:29-31, however, is another question and will have to be tested.

It is not an issue that the words of Paul which are relevant here should be read and understood against an eschatological (Bultmann 1968:186; Conzelmann 1968:307; 1969:158; Klein 1982:282; Froitzheim 1982:25) or perhaps more specifically an apocalyptic (Schrage 1964:139; Schulz

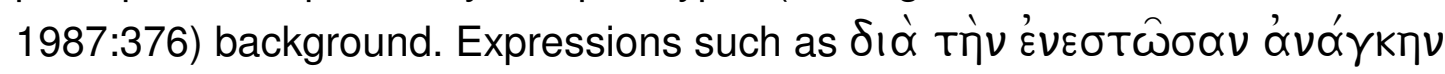

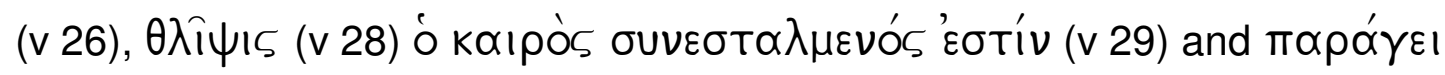
$\kappa \tau \lambda$ ( $v 31$ ) indisputably point in this direction (rightly so inter alia Conzelmann 1969:158; Schrage 1995:171). The question is, of course, what all this implies and whether it excludes the possibility that Paul aligns himself here with Stoic thinking. Some (e g Schulz 1987:376; cf Barrett 1968:178; Lohse 1974:100), maintain like Schrage, that the eschatological or apocalyptic character of Paul's words exclude a relation to Stoic thought. Others hold that this need not be the case (Conzelmann 1969:158; cf Bornkamm 1969:212) or that a combination of the Stoic and the apocalyptic elements is quite conceivable (Deming 1995:192-197). Although there are insufficient grounds to deny that Paul may have been at least partly influenced by Stoic thought, it is indisputably true that his statements in 1 Corinthians 7 should be evaluated solely against the background of the Christ event. As mentioned above, for the Stoic the ideal of living at a distance from worldly matters can be achieved by an inner withdrawal from the world. For Paul, however, it is evidently not something a person decides to do on his/her own initiative or that he/she can achieve merely through an inner withdrawal. For the Stoic, it is something that has to be pursued daily, regardless of time or circumstances. For Paul it is inseparable from the new dispensation that came about through Christ.

No proof is needed that it was Paul's conviction that the community of faith which had come into being through faith in the gospel, not only constituted a completely new community in the worldly dispensation, but also presented itself as an eschatological phenomenon at this juncture. In this case, the term "eschatological" should not only be understood in terms of the temporal dimension, in other words in terms of the fact that in Paul's view it was a foregone conclusion that the world would continue to exist for a brief time only and that the church therefore in this sense was a phenomenon of 
the final days. On the contrary, it should in the first place be understood qualitatively as referring to the church as a completely different community of people who are no longer part of this world and whose citizenship is no longer an earthly, but a heavenly citizenship (see Becker 1989:262). Becker is right when he states that if account is taken of how religion, culture and politics formed a symbiotic unit in the world of antiquity, then it cannot be overemphasised what a rift their faith in the gospel caused for Christians and how profoundly the conversion to Christianity changed people's lives (Becker 1989:263). But although conversion to Christianity meant for the believer a rift and a confrontation with the religions prevailing at the time and in the world of the New Testament, it was not possible to transplant the faith into the areas of culture, politics and society too. The primary reason for this would probably have been the practical problem that it was simply not possible for the handful of Christians to transform the world of their time and place to their liking, or to "christianise" all of its parts. However, the question remains whether this can be adduced as the sole reason. If it has to be accepted that this was the only reason, the path of asceticism would still be open to Christians - something with which they were not unfamiliar in their environment. They evidently did not choose this option, a fact that has often been mentioned in the annals of research.

This was undoubtedly more than a practical problem for Paul, as it related to his view of the church as a new and qualitatively different community, an eschatological community. As suggested above, typifying the church as an eschatological phenomenon should in the first place be understood as referring to the form of the church. And if one were to ask what, in view of Paul's understanding of the church, characterised this existential form, it is clearly the freedom of the Christian (Conzelmann 1968:307; cf also Schrage 1995:172). This freedom consists on the one hand in my being freed from belonging to and depending on this world, from my concern about myself and my salvation, and on the other that to me the world is temporary and has come to an end (cf Klauck 1984:56).

But this is by no means the end of the matter. After all, Paul realised that no matter how real the new dispensation in Christ was, the old dispensation had not yet come to an end, that the church had to lead its life in the old dispensation. But the church's non-worldly character means that it cannot lead this life in the world in any other way than by means of a dialectical relation to the world (see Schrage 1982:193; 1995:175; and cf Conzelmann 1968:281). Therefore, fleeing from and hankering after the world are both excluded for the church. And this is evidently how Paul's viewpoint in 1 Corinthians 7:17-31 should be understood, that is to say as regards 
"remaining in the position" in which the faithful found themselves when they adopted the faith and the "continued participation" in matters of the world after they had become believers.

There is virtually unanimous agreement that Paul's call to maintain a certain freedom from the world was not motivated by a sense of pessimism, cynicism, scepticism, asceticism, mysticism or a dualistic disdain of things material (see inter alia Botman \& Smit 1988:74; Strobel 1989:128). But just as he rejected contempt for and fleeing from this world as options for Christians, he also rejected idolisation of and desire for it. So it seems he opted for a critical middle road between worldliness and divesting from worldliness (see Schrage 1982:193; Klein 1982:282). But what does this mean for the life of the faithful in this world? Or, to put it differently, what exactly could be deduced from the expression $\omega$ 's $\mu$ in in this context? And could what is said here of the believers' relation to the world also be applied to the church as a collection of believers, the church as a so-called "institute"?

What seems obvious in the first place is that what Paul says about participation in the matters of the world is expressed as permission, so to speak, and not as prescription. This is also in line with the advice he offers in 1 Corinthians 7 about marrying or not marrying. Although he does not disapprove of people getting married, he nevertheless states clearly that because of the troublesome times ahead in the near future (verses 26, 27) and for the sake of dedication to the Lord (verses 32-35) it is better not to marry $(v 38,40)$. It therefore appears that he does not insist that the faithful must participate in worldly things, but that if they do, it should be in an "as if not" manner. As mentioned above, he has two reasons for adopting this attitude to the world. On the one hand, it is that in Christ the believer has been separated from the world, and on the other that the world has become an ' $\delta$ ' $\alpha$ ' $о \rho \circ v$ because of the believer's bond with Christ and because the world is coming to an end. Essentially, the faithful have become "indifferent" to the world and they should therefore take a position of neutrality, of $\alpha$ ' $\alpha \rho \alpha \xi^{\prime} \mid \alpha$, to the world even if they would still be involved with or participate in the things of the world.

If the above interpretation does justice to Paul's thinking about the present matter, would it mean that there is nothing in this world that could be regarded as valuable and that the Christian should therefore adopt a negative attitude to everything that is and happens in the world? This question can be answered by stating in the first place that besides the fact mentioned above that Paul regarded the church as an exclusive community compared with the world, his pronouncements about the Christian's relation to the world were so strongly determined by his Naherwartung that it is virtually impossible to say 
how he would have judged the matter had he not expected the end of the world so soon. When he wrote his advice to the Christians in Corinth, he simply did not foresee that the church would have to continue to exist for more than just a few years; it is known that he expected Christ's second coming to take place during his own lifetime (1 Cor 15:51; see also 1 Th 4:16-17). This is not to suggest that if he had known that the church would have had to find a home in this world for many centuries to come, he would have advised the church to just become submerged in the world. The fact is simply that his advice related only to the relatively short period of existence he foresaw for the church in this world. This is why the easiest answer to the above question would have been simply to say: "We don't know" or "That is a non-question". In terms of the stated historical contingency of the text, such a reply would be partly justified, but not altogether satisfactory. It does not satisfy because the Naherwartung is not Paul's only reason for his advice; as stated above there, is also the fact that the church has already been separated from the world, i e that it is entweltlicht. One could naturally ask how long he would think that even an entweltlichte church would be able to maintain such a $\omega_{s} \mu$ ń attitude toward the world, but we will not pursue this point.

So how should we answer the question whether Paul took a negative view of worldly institutions per se? Our response is that although he expects Christians not to conform to the world ( $\mathrm{Rm} 12: 2)$, he does not actually judge these institutions negatively but merely declares them to be transient and obsolete. Stated differently, one would at least be unable to find sufficient grounds to accuse him of cultural enmity. What he was convinced of was that a cultural product or worldly institution was, in view of the Christian's new bond with Christ and his/her new, eschatological, existence irrelevant to the Christian's religious life. But for the same reason, one can hardly expect him to take a positive view of things that, when all is said and done, were not relevant. Claiming that he probably did not have a negative attitude to everything per se need not imply therefore that he might have had a positive attitude to some things. It should be pointed out that he did think people had to fulfil their civic obligations (Rm 13:1-7) and carry out their everyday duties in society (1 Th 4:11), in which regard he himself set an example (1 Cor 4:12). As is clear above, the case of Romans 13:1-7 is especially problematic. Even if the possibility that it may be an interpolation is rejected, it is generally accepted that we have here a typical synagogic approach to our relation with the authorities. If we are in fact dealing with Paul himself here, or with a view that he supported, the least we can deduce from it is that in his opinion a Christian should be law-abiding and not be a rabble-rouser or rebel against 
authority. He and his readers certainly would not have had any doubts about the risk of rebelling against the authorities of their day and age. In the above discussion of his pronouncements in 1 Corinthians 7:17-24, we note too that in his view one should not believe that one had to change one's position or status or social ties in society because one had become a Christian or because one wanted to become an even better Christian. In his view, therefore, one could not and should not withdraw from civil society. And although he castigated the practice among Christians of attempting to have their mutual disputes settled in worldly courts, he did not reject the secular legal institutions or practice as such.

Even if there is a dearth of data, we may with a reasonable degree of certainty conclude that Paul must have had a fairly positive attitude to at least the institutions necessary for the daily functioning of society, even if this was only for the short period left to the world. In this light, he would probably have not expected Christians to withdraw from what could be described as cultural activities in his time. That he would also encourage Christians to take an active part in cultural matters does appear extremely unlikely from the information available. But if the improbable were nevertheless the case, he would undoubtedly, and especially in this regard, have set the condition that the Christian's involvement should in no way hinder his/her dedication to the Lord. In other words, what is said in 1 Corinthians 7:32-35 that a man or woman ought to be without worldly concerns with a view to dedication to the Lord, can with good reason be made equally applicable to the Christian's participation in any worldly activity. Therefore, besides Paul's statement that participation in worldly, or alternatively cultural, activities has no redemptive value, he would in this case also definitely have said that he wished the Christian, with a view to dedication to the Lord, to be árúpı 7:32), and that it should rather be said of the Christian $\mu \varepsilon \rho ı \mu \nu \hat{\alpha}$ tó toû

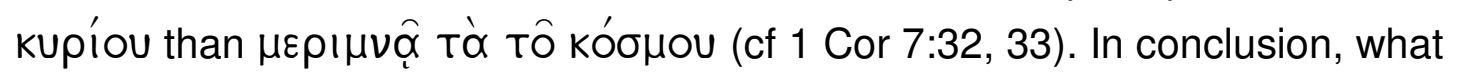
should be stressed regarding the Christian's participation in the things of the world is that in no case, so to speak, does it concern participation in faith. In other words, the Christian's participation in these things is not a manifestation of his/her belief, although he/she naturally participates in them as a believer. It is an important fact to bear in mind, as it has implications for the question of the relation between the church and the world.

If the above is a correct interpretation of Paul's view of the relation of the individual Christian to the world, what does this imply for the church's relation to and role in the world? Adding to the difficulty of answering this question is for example the fact that Paul did not know the church of his day as the institutional entity it has become today. To him the church was in a 
certain sense the assembly of individual believers, although he did not see it as merely the sum total of the faithful, but as preceding in time and substance the sum total of the individual believers (see Bultmann 1968:311; Conzelmann 1968:281, 289; Bornkamm 1969:185; Pelser 1994:320-321). Nevertheless, even if the modern concept of the church is taken as point of departure, it can hardly be assumed that Paul would have evaluated the situation of the church differently than that of the individual believer. He would therefore have expected the church to remain as eschatologically free and uncompromised as the individual believer. Furthermore, in the case of the church, it could not happen in any other way than dialectically, so that fleeing from the world could be as poor an option as desiring it, and despising the world as poor an option as idolising it.

And yet, even if it should be said of the church that it is in the same dialectical relation to the world as the individual believer, a relation of neither giving up the world nor becoming like it, it appears that broadly seen, there is sufficient reason to assume that the situation of the church does differ from that of the individual believer. The church as the body of Christ cannot be regarded in any other way than as being qualitatively different and distinguishable from the world (see Pelser 1994:323). Unlike the individual believer, who cannot do otherwise than continue to live in the world and who may, according to Paul, also participate in worldly things, the church because of its very nature and calling - cannot have a worldly commitment and programme, no matter how meritorious such a programme might seem. Whereas the individual believer, bearing in mind the above-mentioned reservations, can therefore be fully involved in cultural activities, ecclesiastical involvement in such activities does not seem to be reconcilable with Pauline thinking about the nature and calling of the church. As pointed out above, the participation of believers in matters of the world is not an expression of their faith, in other words it is not manifestations of faith that are expressed in this way. What goes for the individual believer, goes in principle even more for the church. Unlike the individual believer, the church does not, strictly speaking, have a civil life in which to participate, and no activity in the area of civil life can be an expression of being church in the world. After all, the church is not

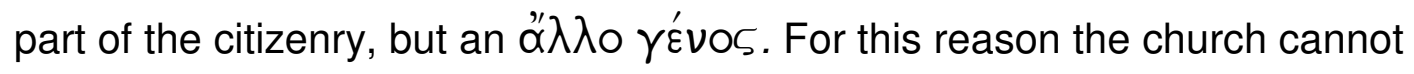
be a partner in a people's or cultural group, and activities such as the promotion of national identity, language, music, art, the celebration of folk festivals and the like, are not the official responsibility of the church, and if the church participates in them, it is moving beyond its territory. Such activities are the right and the responsibility of the members of a people, and therefore only of members of the church in so far as they are members of a particular 
nation or cultural group. As already noted above with regard to individual believers, it is even more unthinkable that Paul would have considered it the duty of the church to encourage people to fight for the retention of a national identity or for the promotion of culture. Although the church uses a cultural product such as language for proclaiming the gospel, the existence of the church is not dependent on the existence or continued existence of a people or a given culture. Consequently, if a nation of people were to cease to exist or change its character, it would not signify the end of the church. The church would then simply cease to exist among the people in question and would continue to work in the new situation. Even education, regardless of its merit or importance, does not seem to be the church's task, equally as it is not the school's task to preach the gospel. Education is the responsibility of the parents, whereas catechism is the task of the church and the parents as believers. The task of the church is nothing more, but also nothing less than to preach the gospel and do its pastoral work in such a way that wherever Christians may be or wherever they are culturally active, they will act as believers and in the process will conduct themselves accordingly. Of course Paul did not express himself in this way about these matters, but it is unlikely that he would have expressed a different view had he been obliged to respond to an enquiry in this regard.

\section{SUMMARY}

Before I sum up, it is necessary to point out that what has been deliberated above on the basis of Paul's pronouncements about the believer or about the participation or non-participation of the church in worldly institutions, consists of nothing more and nothing less than deductions which, in my opinion, can rightly be made on the basis of these pronouncements. Therefore they should not be seen as prescriptive for all times and circumstances. I have also indicated that it cannot be left out of account that Paul's view is to a large degree situationally determined and in accordance with his world view - a world view that we no longer or no longer completely share. Nevertheless, I wish to emphasise that his convictions were not determined solely by his Naherwartung, but definitely also by his view of the qualitative difference of the community of the faithful (church) as an eschatological phenomenon. It is with this Pauline thinking that I can identify, because it seems to me the most acceptable in principle as regards the question of the relation between the church and the world/culture.

If my line of reasoning has produced a reasonable version of the Pauline viewpoint(s) about the matter at hand, the conclusion appears 
warranted that although Paul does not expect believers to withdraw from the world, he does at least expect them to maintain a critical distance from everything in the world. Apart from the transience and the impending end of the world and everything in it, he held that Christians, owing to their new bond and identity, should remain free of attachment to the world, even if they were still involved in worldly activities and institutions. The root of the matter is therefore that Christian freedom is decisive, namely the freedom to participate or be involved in everything, but with a very pertinent reservation: not to allow yourself to be dominated by it ( 1 Cor 6:12), for then your freedom is gone, and your freedom to participate may not get in the way of undivided dedication to the Lord (1 Cor 7:35).

It has also become clear that Paul nowhere encourages believers to participate in worldly practices. What he says about participation he expresses as permission, that is: you can, not: you shall. What he says about marrying and not marrying in 1 Corinthians 7:35-40 may rightly be extended to other fields of a Christian's life. That means Paul would also judge, regarding other things with which one normally gets involved in this world, that where possible one should rather not participate in them for the sake of dedication to the Lord. Participation or non-participation in worldly activities does not contribute to a Christian's salvation, and where salvation is concerned, should be regarded as ' ' $\delta ı$ ' $\phi о p \alpha$. Conversely, although Christians' participation in such activities is not a manifestation of their faith; their manner of participating is.

What applies to the individual Christian obviously also applies to the church. And yet it has to be accepted that the situation of the church differs from that of the Christian in an important respect, namely that the church does not form part of society, even if the church is found nowhere else but in society. The fact that the church, which is more than the individual believer, does not originate from society or from the citizenry and is not part of it, means that the church has no cultural task of whatever kind to perform there. The task of the church ends with its responsibility to make the individual believer live and act like a Christian, wherever in the world the believer may be or whatever he or she may be involved in. Apart from the calling to proclaim God's saving grace to the world, the church has one other obligation, and that is the obligation to charity.

\section{Works consulted}

Barrett, C K 1968. The first epistle to the Corinthians. London: Adam \& Charles Black. (BNTC.)

Becker, J 1989. Paulus: Der Apostel der Völker. Tübingen: Mohr.

Betz, H D 1979. Galatians. Philadelphia, PA: Fortress. (Hermeneia.) 
Bornkamm, G 1969. Paulus. 2. durchgesehene Aufl. Stuttgart: Kohlhammer. (UTB 119.)

Botman, H R \& Smit, D J 1988. 1 Corinthians 7:29-31 "To live - as if it were not!" JTSA 65, 73-79.

Bultmann, R 1968. Theologie des Neuen Testaments. 6. durchgesehene Aufl. Tübingen: Mohr.

Conzelmann, H 1968. Grundriss der Theologie des Neuen Testaments. Kaiser Verlag: München.

Conzelmann, H 1969. Der erste Brief an die Korinther. Gottingen: Vandenhoeck. (KEK V.)

Deming, W 1995. Paul on marriage and celibacy: The Hellenistic background of 1 Corinthians 7. Cambridge: Cambridge University Press. (MSSNTS 83.)

Diogenes Laertius 1938. LCL.

Epiktetus 1928. Dissertationes III \& IV. LCL.

Froitzheim, F 1982. Christologie und Eschatologie bei Paulus. 2. Aufl. Freiburg: Herder.

Käsemann, E [1951] 1960. Begründet der neutestamentliche Kanon die Einheit der Kirche?, in Exegetische Versuche und Besinnungen, I, 214-223. Gottingen: Vandenhoeck.

Käsemann, E 1972. Das theologische Problem des Motivs vom Leibe Christi, in Paulinische Perspektiven, 178-210. 2.Aufl. Tübingen: Mohr.

Käsemann, E 1974. An die Römer. 2. durchgesehene Aufl. Tübingen: Mohr. (HNT 8a.)

Klauck, H-J 1984. 1. Korintherbrief. Würzburg: Echter. (NEB.NT 7.)

Klein, G 1982. s v Eschatologie. TRE.

Lohse, E 1974. Grundriss der neutestamentlichen Theologie. Stuttgart: Kohlhammer. (ThW 5.)

Neyrey, J H 1990. Paul in other words: A cultural reading of his letters. Louisville, KY: Westminster.

Oepke, A 1964. Der Brief des Paulus an die Galater. Berlin: Evangelische Verlagsanstalt. (ThHK 9.)

Pelser, G M M 1994. Enkele opmerkings oor die wese van die kerk. HTS 50, 311 329.

Pelser, G M M 1995. Die kerk in die Nuwe Testament. HTS 51, 654-676.

Riekkinen, V 1980. Romer 13: Aufzeichnung und Weiterführung der exegetische Diskussion. Helsinki: Suomalainen Tiedeakatemia. AASF. (Dissertasiones Humanarum Litterarum 13.)

Roloff, J 1993. Die Kirche im Neuen Testament. Gottingen: Vandenhoeck. (GNT 10.)

Schade, H-H 1984. Apokalyptische Christologie bei Paulus: Studien zum Zusammenhang von Christologie und Eschatologie in den Paulusbriefen. 2. überarbeitete Aufl. Gottingen: Vandenhoeck. (GTA 18.)

Schmithals, W 1975. Der Römerbrief als historisches Problem. Gütersloh: Gerd Mohn. (StNT 9.)

Schmithals, W 1994. Theologiegeschichte des Urchristentums: Eine problemgeschichtliche Darstellung. Stuttgart: Kohlhammer.

Schnackenburg, R 1974. The church in the New Testament, translated by W J O'Hara. London: Burns \& Oates. 
Schrage, W 1964. Die Stellung zur Welt bei Paulus, Epiktet und in der Apokalyptik:

Ein Beitrag zu 1 Kor 7, 29-31. ZThK 61, 125-154.

Schrage, W 1982. Ethik des Neuen Testaments. Göttingen: Vandenhoeck. (GNT 4.)

Schrage, W 1995. Der erste Brief an die Korinther. 2. Teilb. Solothum: Benziger. (EKK VII/2.)

Schulz, S 1987. Neutestamentliche Ethik. Zürich: Theologischer Verlag. (ZGB.)

Strobel, A 1989. Der erste Brief an die Korinther. Zürich: Theologischer Verlag. (ZBK6, 1.)

Weiss, J [1910] 1970. Der erste Korintherbrief. Gottingen: Vandenhoeck. (KEK.) 